\title{
Magyar Eupitheciini tanulmányok 8. Herczig Béla Eupitheciini gyüjteménye Kaposváron (Lepidoptera: Geometridae)
}

\author{
FAZEKAS IMRE
}

\author{
Pannon Intézet, 7625 Pécs, Magaslati út 24., Hungary \\ e-mail: fazekas@outlook.com
}

\begin{abstract}
FazeKas I.: Hungarian Eupitheciini studies, No. 8. The Eupitheciini collection of the Béla Herczig, Kaposvár, Lepidoptera, Geometridae.

Abstract: One of the most important Lepidoptera collections in Hungary is deposited in the Museum RipplRónai, Kaposvár. Several private collectors donated their own collections to the museum, the agronomist Béla Herczig is among them. In the present paper the author elaborated the Eupitheciini material of the Herczigcollection, what included 60 species. More than several hundred specimens have been collected in 86 Hungarian localities. The moths were collected at light by the hand of Béla Herczig or by semi-automatic light-traps between the years of 1971 and 1992. The author lists the flight-period data and the collecting localities of the species. In the case of species or species-pairs posing identification problems genitalia examinations have been carried on. After studying, the genital parts were stored in a microvial containing glycerine, which was attached to the same pin as the exemplar. The important observations are given in remarks. The following species are discussed in detail: Eupithecia absinthiata, E. insigniata, E. innotata, E. ochridata. The paper is illustrated by several distributional maps, moth images and genitalia figures.
\end{abstract}

Keywords: Lepidoptera, Geometridae, Eupitheciini, faunistic, biology, distribution, Hungary.

\section{Bevezetés}

Az elmúlt évben jelent meg a kaposvári Rippl-Rónai Múzeum Eupitheciinigyüjteményét feldolgozó tanulmányom (FAzEKAs 2017). Ezt követően - szintén 2017ben - adományként került a múzeumba Tatáról Herczig Béla agrármérnök magángyüjteményének Geometridae anyaga. Jelen munkámban ennek a gyüjteményrésznek az Eupitheciini példányait revideáltam.

Herczig Béla 1948-ban született Tatán. Az Eötvös József Gimnázium elvégzése után a Keszthelyen agrármérnöki diplomát szerzett. Egyetemi doktorátusát "Fénycsapdák az entomológiai kutatás és a prognosztikai gyakorlat szolgálatában" című disszertáció alapján kapta meg 1985-ben. 1971-ben a Komárom Megyei Növényvédő Állomáson kezdett el dolgozni, majd hét éven át Budapesten a MÉM Növényvédelmi és Agrokémiai Központ munkatársa volt, ahol az országos növényvédelmi fénycsapdahálózat (20 csapda) anyagának feldolgozása, a hálózat felügyelete és fénycsapdás elörejelzések készítése volt a feladata. 1979-ben visszakerült a tatai Növényvédő Állomásra, mint a rovartani szakterület felelőse. 


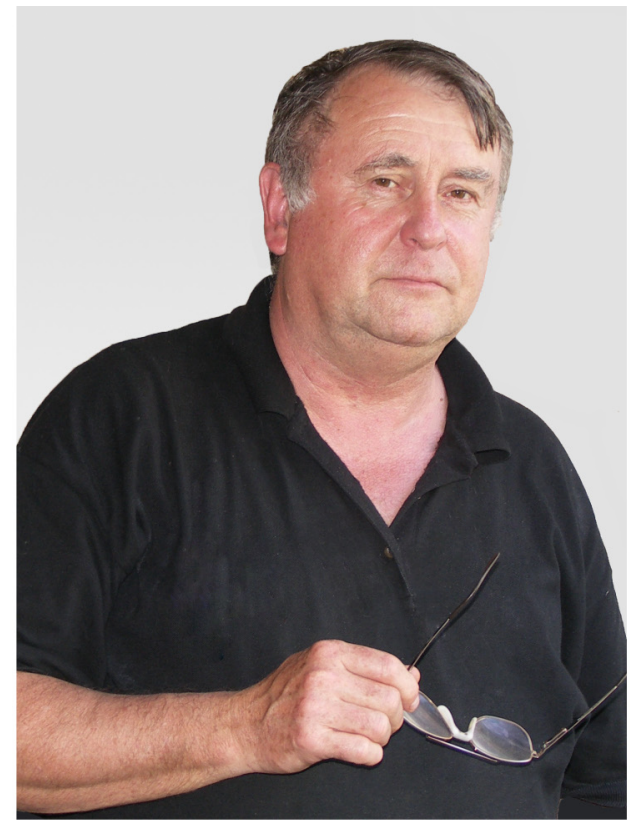

1

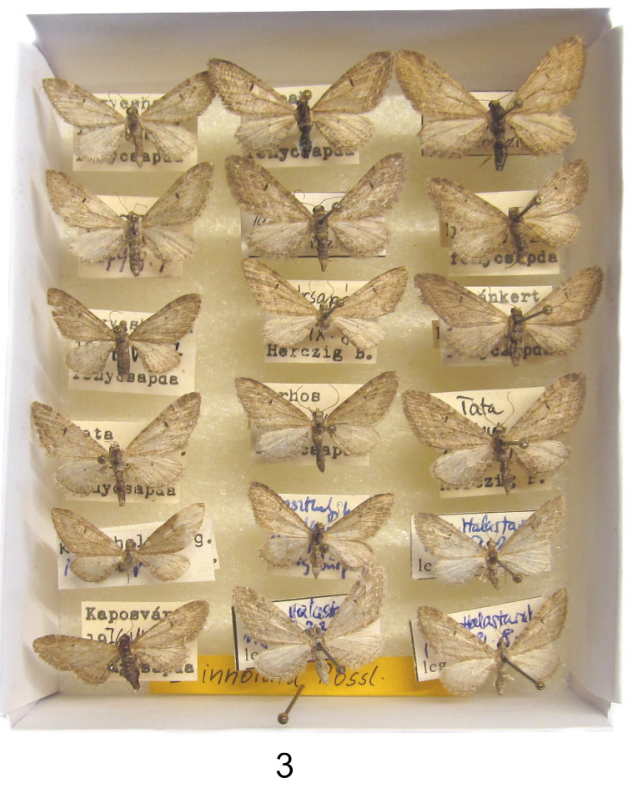

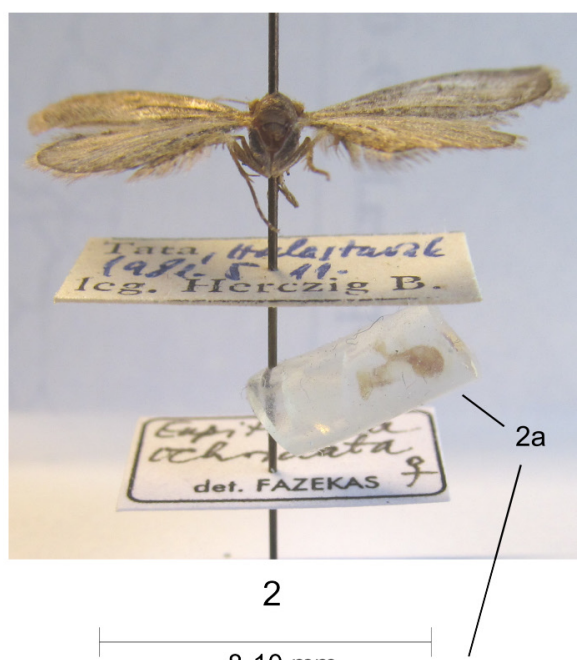

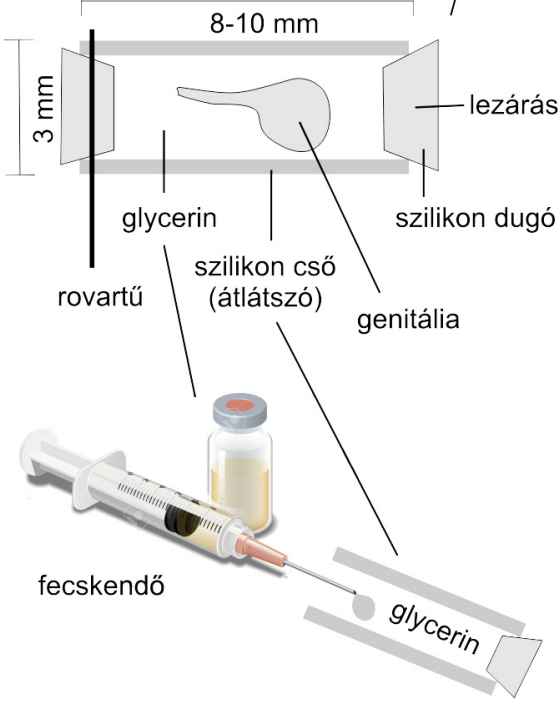

$2 a$

1-3. ábra: 1. Herczig Béla; 2. A genitália preparátum elhelyezése szilikon csőben, 97\%-os glycerinben; 3. Részlet a Kaposvárott őrzött Herczig-gyüjteményből 
A lepkék - különösen a szenderek - már kora gyermekkorában felkeltették az érdeklődését. Kezdetben a hazai lepkefaunát gyüjtötte; tervszerüen kutatta a Gerecse, a Vértes és a Keszthelyi-hegység lepkefaunáját. Részt vett a "Bakony természeti képe" és a "Vértes és Gerecse lepkevilága" programban. Később, ahogy az anyagi és politikai lehetőségek megengedték, a Balkánon, majd Törökországban, az Észak-Kaukázusban, Türkméniában, Pakisztánban, Iránban, Nepálban és Tajvanon számos expedíciónak volt tagja. Sajnos az expedíciókat egy 2002-ben elvégzett csípőprotézis-mütét miatt nem folytathatta tovább.

Eddig közel 100 önálló és társszerzőkkel, főként növényvédelmi témában készített dolgozata, s két könyvrészlete jelent meg. Mintegy 80000 példányt számláló gyüjteményének zöme Ronkay Gáborhoz, kisebb része a Magyar Természettudományi Múzeumba került. Araszóló lepke gyüjteményét a kaposvári Rippl-Rónai Múzeumnak adományozta. Jelen tanulmányban a Kaposvárott őrzött Eupitheciini anyagot mutatom be, melyet később más Geometridae taxonok is követni fognak.

\section{Anyag és módszer}

A lelöhelycédulákon szereplö gyüjtési helyeket abc-sorrendben közlöm. Az imágók repülési idejét római számokkal jelölöm. Lelöhelyek elnevezéseinél a cédulákon olvasható eredeti neveket írtam le. A gyüjteményben található ritka példányok (1-3 ex) esetében a cédulák teljes adatsorát közlöm. Gyüjtések intervalluma több mint két évtized: 1971-től 1992-ig tartott. Gyüjtők névjegyzéke: Buschmann Ferenc, Bürgés György, Ganev Julius (BG), Herczig Béla, Mészáros Zoltán, Ronkay Gábor, Ronkay László, Szabóky Csaba. A példányok jelentős részét Herczig Béla gyűjtötte (1. ábra); számos példány származik a növényvédelmi fénycsapdákból.

Az elkészített genitália preparátumok euparalban rögzített kisebb része a pécsi Pannon Intézetben van elhelyezve. Azért, hogy az ivarszervek térszerkezetét a későbbiekben is tanulmányozni lehessen, a vizsgálati anyag legtöbb példányának genitáliáját 97\%-os glicerinben tartósítva, szilikon csőben, a rovartüre tüztem (2-3. ábra), s a kaposvári Rippl-Rónai Múzeumban találhatók. Az imágók képei Sony DSC-H100v fényképezögéppel és Zeiss sztereó mikroszkópra szerelt BMS tCam 3,0 MP digitális kamerával készültek, a ScopePhoto 3.0.12 szoftver segítségével. A genitális fotókat a Scopium XSP-151-T-Led biológia mikroszkóppal és a számítógéphez csatlakoztatott MicroQ 3.0 MP digitális kamerával készítettem 20x-os és 50x-es nagyítással.

\section{A vizsgált lelöhelyek jegyzéke}

Ha áttekintjük a lelőhelyek térképét (4. ábra), akkor jól látható, hogy Herczig Béla gyüjtőhelyei döntően a Dunántúli-középhegység területére esnek. Más nagytájakról csak szórványosan vannak példányok. A 86 magyarországi lelöhelyet az alábbiakban olvashatjuk abc-sorrendben: 


\begin{tabular}{|c|c|}
\hline Ágasegyháza & Koponár \\
\hline Alsóvadács & Kőszeg \\
\hline Apátistvánfalva & Mikepércs \\
\hline Baj & Miskolc \\
\hline Bajna & Nadap \\
\hline Bakony (Darvas-tó, Feketevízpuszta, Széki-erdő) & Nagyharsány \\
\hline Balassagyarmat & Nagytétény \\
\hline Bársonyos & Nyársapát \\
\hline Bokod & Nyékládháza \\
\hline Budai-hegyek (Farkas-hegy) & Nyirád \\
\hline Budapest (Hármashatár-hegy, Írhás-árok & Ócsa \\
\hline Budaörs (Odvas-hegy) & Pacsa \\
\hline Börzsöny („Kisinóc tt.”), & Pápa \\
\hline Brennbergbánya & Pécs (Jakab-hegy) \\
\hline Csákvár & Piliscsaba \\
\hline Csopak & Rezi \\
\hline Eger & Salföld \\
\hline Fácánkert & Sárvár \\
\hline Gánt & Somlóvásárhely \\
\hline $\begin{array}{l}\text { Gerecse (Bocsájtó-völgy, Kőpite-hegy, Zuppa-hegy, } \\
\text { Zsidó-hegy, Vörös-rét, Vég-kő) }\end{array}$ & Sopron \\
\hline Gönyü & Szár \\
\hline Hegyeshalom & Szederkény \\
\hline Hegyhát & Zempléni-hegység (Rostalló) \\
\hline Hódmezővásárhely & Tanakajd \\
\hline Jászberény & Tarhos \\
\hline Ivánc & Tass \\
\hline Kám & Tardosbánya \\
\hline Kaposvár & Tarhos \\
\hline Kenderes & Tata \\
\hline Keszthely & Vállus \\
\hline $\begin{array}{l}\text { Keszthelyi-hegység (Bece-hegy, Fagyoskereszt, } \\
\text { Feszeskereszt, Nagylapos, Puskaporos allé, } \\
\text { Tusakos, Vadlány-barlang }\end{array}$ & $\begin{array}{l}\text { Várgesztes } \\
\text { Velem }\end{array}$ \\
\hline Kisbér & \\
\hline
\end{tabular}




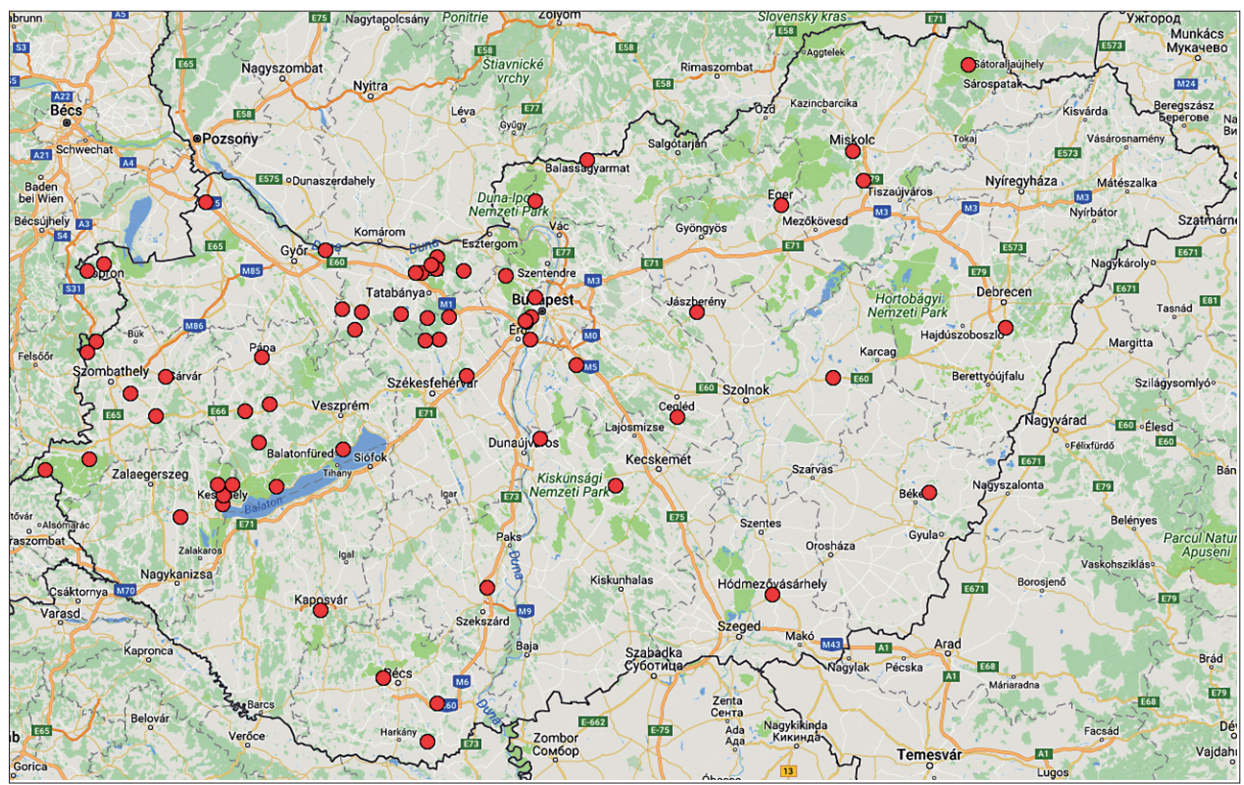

4. ábra: A gyűjtőhelyek földrajzi elhelyezkedése Magyarországon

\section{Faunisztikai adatok és jegyzetek}

1. Chloroclystis v-ata (Haworth, 1809) (= coronata (Hübner, 1813)

Imágó: V-VIII. Lelőhelyek: Nagymaros (Gesztenyés), Keszthelyi-hegység (Feszeskereszt, Tusakos), Rezi, Tata.

\section{Eupithecia abbreviata Stephens, 1831}

Imágó: IV. Lelőhelyek: Zempléni-hegység (Rostalló), Ivánc.

\section{Eupithecia abietaria (Goeze, 1781) (= pini (Retzius, 1783)}

Imágó: VI-VII. Lelöhely: Kisbér.

\section{Eupithecia absinthiata (Clerck, 1759) (= catharinae Vojnits, 1969)}

Imágó: V., VII., VIII., IX. Lelöhelyek: Balassagyarmat, Budapest (Irhás-árok), Brennbergbánya, Fácánkert, Ivánc, Kaposvár, Keszthely, Mikepércs, Nadap, Pacsa, Pápa, Rezi, Sárvár, Somlóvásárhely, Tanakajd, Tarhos, Tata.

Jegyzet: A megvizsgált példányok mintegy 50\%-a az E. catharinae név alá volt besorolva, mely szinte általános a magyarországi magán gyüjteményekben. Az absinthiatacatharinae „fajpár” taxonómiai probléma körével részletesen foglalkoztam (vö. FAZEKAS 2016). A catharinae típusanyag revíziója során bebizonyosodott, hogy a catharinae az igen formagazdag absinthiata szinonimája. Az 1970-es évektől megjelent faunisztikai munkákban közölt „,catharinae” adatokat E. absinthita-nak kell tekinteni.

\section{Eupithecia alliaria Staudinger, 1870}

Imágó: VII-VIII. Lelőhelyek: Gánt (Róka-hegy), Nagyharsány (Szársomlyó). 
6. Eupithecia analoga europaea Lempke, 1969 (= bilunulata (Zetterstedt, 1839)

1 ô, Fácánkert, 1978.VI.9. fénycsapda.

7. Eupithecia assimilata Doubleday, 1856

Imágó: V; VII-VIII. Lelöhelyek: Balassagyarmat, Bársonyos, Bokod, Brennbergbánya, Eger, Ivánc, Kaposvár, Kisbér, Pacsa, Pápa, Tanakajd, Tata.

8. Eupithecia breviculata (Donzel, 1837)

1 ô, Nadap, 1978.VII.27. fénycsapda.

Jegyzet: A magyarországi populációk erősen izoláltak a mediterrán térségek népességeitől (vö. MironOv 2003, p. 223).

9. Eupithecia centaureata (Denis \& Schiffermüller, 1775) (= oblongata (Thunberg, 1784) Imágó: V-VIII. Lelöhelyek: Budaörs (Odvas-hegy), Keszthelyi-hegység (Koponár), Tata.

10. Eupithecia denotata (Hübner, 1813)

Imágó: VI-VII. Lelőhelyek: Alsóvadács, Brennbergbánya, Csákvár, Várgesztes, Tata.

11. Eupithecia distinctaria Herrich-Schäffer, 1848

Imágó: V-VIII. Lelőhelyek: Budai-hegyek (Farkas-hegy), Tata, Tardosbánya, Várgesztes.

12. Eupithecia dodoneata Guenée, 1857

Imágó: IV-V. Lelöhelyek: Balassagyarmat, Csákvár, Kaposvár, Keszthelyi-hegység (Hegyhát, Vállus), Rezi, Tata, Várgesztes.

Jegyzet: A csákvári példányok (3 ex) rajzolatmentesek, egyszínü barnásszürkék voltak (gen. prep. Fazekas I.).

13. Eupithecia egenaria Herrich-Schäffer, 1848

1 đે, Vértes, Várgesztes, 1979.5.28., fénycsapda; 1 ㅇ, Bakony (Feketevízpuszta), 1985.6.1., Herczig B.

Jegyzet: Magyarországon igen lokális és ritka euro-kaukázusi faunaelem. Hernyója kizárólag a Tilia fajokat preferálja (FAZEKAs 2016).

14. Eupithecia ericeata (Rambur, 1833)

7 ex, Pécs, Jakab-hegy, 1978.IX.22., 24; X.2-6. fénycsapda.

Jegyzet: Új faj a Mecsek faunájában. Diszjunkt szubmediterrán faj; eddig csak Szíriából, Kis-Ázsiából, a Kaukázus vidékéről, Dél-Európából és Közép-Európa déli tájairól ismert. Hernyóit Erica-, Juniperus- és Cytisus fajokon találták meg.

15. Eupithecia extraversaria Herrich-Schäffer, 1852

Imágó: VI-VIII. Lelőhelyek: Ágasegyháza, Brennbergbánya.

16. Eupithecia graphata (Treitschke, 1828)

Imágó: VI., VIII. Lelöhelyek: Csopak, Gerecse (Zuppa-hegy, Zsidó-hegy), Keszthelyihegység (Bece-hegy, Puskaporos allé, Nagylapos), Rezi.

17. Eupithecia gueneata Milliére, 1862

2 q, Keszthelyi-hegység (Koponár), 1979.8.3-4. Herczig B.

Jegyzet: Regresszióban lévő faj. Magyarországon főként a száraz gyepekben, a kaszálóréteken, a sziklagyepekben, a lejtősztyeppeken és a karsztbokorerdőkben gyüjtötték; igen lokálisan (FAZEKAS 2017). 
18. Eupithecia haworthiata Doubleday, 1856

Imágó: V-VI; VIII. Lelőhelyek: Balassagyarmat, Budapest (Irhás-árok, Orbán-hegy), Brennbergbánya, Csopak, Kaposvár, Pacsa, Pécs (Jakab-hegy), Tardosbánya.

19. Eupithecia icterata (Villers, 1789)

Imágó: VIII-IX. Lelőhelyek: Balassagyarmat, Brennbergbánya, Budai-hegyek (Irhásárok), Gerecse (Vég-kő), Keszthely, Rezi, Szederkény, Tata.

20. Eupithecia impurata (Hübner, 1813)

Imágó: VIII. Lelőhelyek: Budai-hegyek (Irhás-árok, Odvas-hegy).

21. Eupithecia indigata (Hübner, 1813)

Imágó: IV-V. Lelőhelyek: Bajna, Sárvár.

22. Eupithecia innotata (Hufnagel, 1767)

Imágó: IV-V; VIII-IX. Lelőhelyek: Budapest (Orbán-hegy), Csopak, Fácánkert, Hegyeshalom, Hódmezővásárhely, Kaposvár, Keszthelyi-hegység (Nagylapos), Mikepércs, Nadap, Nagyharsány (Szársomlyó), Nagytétény, Nyársapát, Pacsa, Pápa, Piliscsaba (Vörös-hegy), Tarhos, Tass, Tata („Halastavak”).

Jegyzet: a példányok egy része az Eupithecia ochridata név alá volt besorolva. Ennek egyik oka, hogy számos helyi innotata forma szárnyának habitusa megtévesztésig hasonlít az ochridata-ra (FAzEKAS 2016, p. 160, 11. ábra). A példányok egzakt azonosítása csak az ivarszervek vizsgálatával volt elvégezhető. Az innotata és az ochridata szimpatrikus előfordulású volt Budapesten (Orbán-hegy), és a tatai halastavaknál. A két taxon legfontosabb differenciális bélyegeit a 5. ábrákon mutatom be.

\section{Eupithecia insigniata (Hübner, 1790)}

1 đ̊, Vértes, Csákvár, 1992.4.28. leg. Herczig B.

Jegyzet: A faj életciklusa, faunaelem és faunakomponens besorolása további vizsgálatokat igényel (FAzEKAS 2017). Repülési idejét Európában márciustól augusztusig figyelték meg. Egyes földrajzi térségekben feltehetőleg két nemzedékes. Jellegzetes habitatjai a Prunus-, Crataegus cserjések, az erdőszegélyek, és a cserjés mezsgyék.

\section{Eupithecia intricata (Zetterstedt, 1839)}

2 đે, Kenderes, 1978.V.27; VI.1., fénycsapda; 1 đે, Nyirád, nyíres-borókás, 1977.V.20. leg. Ronkay L.

Jegyzet: Új faj az Alföldön.

25. Eupithecia inturbata (Hübner, 1817)

Imágó: IV; X. Lelöhelyek: Rezi, Várgesztes.

Jegyzet: Európában univoltin; VI-X. (Mironov 2003) Az április magyar példány feltehetőleg két generációra utal, de ezt további vizsgálatoknak kell megerősítenie.

26. Eupithecia lanceata (Hübner, 1825)

1 Õ, Zempléni-hegység, Rostalló, 1977.IV.7. leg. Ronkay G.

27. Eupithecia lariciata (Freyer, 1841)

Imágó: V-VII. Brennbergbánya, Rezi, Sopron (Fáber-rét, Poloskás-bérc). 

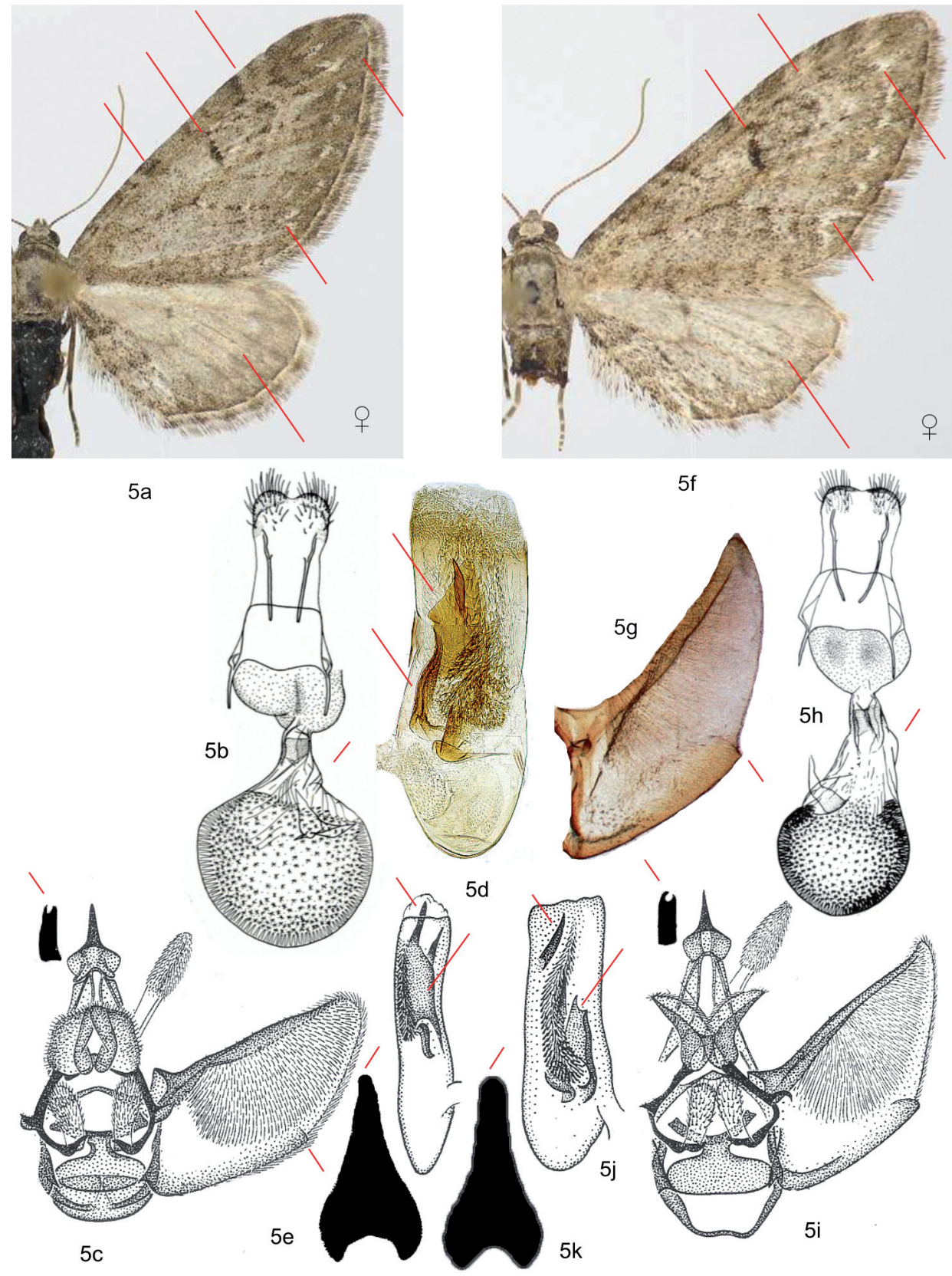

5. ábra: Az Eupithecia innotata és az $E$. ochridata fajpár diagnosztikus bélyegei;

5a. $E$. innotata, imágó; $5 b$. nőstény genitália; $5 \mathrm{c}$. hím genitália; $5 \mathrm{~d}$. aedeagus (hím);

5e. VIII. sternit (hím); - 5f. E. ochridata, imágó; 5g. valva (hím); 5 h. nőstény genitália; 5i. hím genitália; 5j. aedeagus (hím); 5k. VIII. sternit (hím) 
28. Eupithecia laquaearia Herrich-Schäffer, 1848

Imágó: VI., VIII. Lelőhelyek: Brennbergbánya, Ivánc, Keszthelyi-hegység (Nagylapos), Sárvár.

Jegyzet: eddig júliusig ismertük magyarországi repülését (FAZEKAS 2016). Hazánkból főként a Dunántúlról és az Északi-középhegységből vannak egzakt adatok.

\section{Eupithecia linariata (Denis \& Schiffermüller, 1775)}

Imágó: VI-IX. Lelőhelyek: Brennbergbánya, Csopak, Eger, Keszthelyi-hegység (Fagyoskereszt, Koponár-Hegyhát), Komárom, Nadap, Pápa, Pécs (Jakab-hegy), Tata (Halas-tó).

30. Eupithecia millefoliata Rössler, 1866 (= wettsteini Vojnits, 1974)

Imágó: VII-VIII. Lelöhelyek: Alsóvadács (Gerecse), Börzsöny („Kisinóc tt.”), Eger, Fácánkert, Gánt, Hegyeshalom, Ivánc, Kaposvár, Keszthelyi-hegység (Nagylapos), Kisbér, Mikepércs, Nagytétény, Nyársapát, Nyékládháza, Pápa, Tarhos.

\section{Eupithecia nanata (Hübner, 1813)}

2 †, Apátistvánfalva, 1979.V.7; Salföld, Ábrahám-hegy, 1983.7.28. leg. Herczig B.

Jegyzet: Új faj az Örségi Nemzeti Park faunájában; európai faunaelem, melynek részteles magyarországi elterjedési térképét korábban közöltem (vö. FAZEKAS 2017, p. 158, 10. ábra).

32. Eupithecia ochridata Schütze \& Pinker, 1968 (= szelenyii Vojnits, 1969)

Imágó: V. Lelőhelyek: Budai-hegyek (Orbán-hegy), Tata (halastavak).

\section{Eupithecia orphnata W. Petersen, 1909}

Imágó: VII-VIII. Lelöhelyek: Keszthelyi-hegység (Puskaporos allé), Pápa, Tata, Velem. Jegyzet: A Keszthelyi-hegységben elöfordulása korábban bizonytalan volt (vö. FAZEKAS 2017, p. 170, 16. ábra).

34. Eupithecia pauxillaria Boisduval, 1840 (= euphrasiata (Herrich-Schäffer, 1861)

2ㅇ, Budai-hegyek, Hármashatár-hegy, 1980.8.30. leg. Herczig B.

\section{Eupithecia pimpinellata (Hübner, 1813)}

Imágó: VI-IX. Lelőhelyek: Balassagyarmat, Bokod, Budai-hegyek (Farkas-hegy, Irhás-árok), Brennbergbánya, Ivánc, Keszthelyi-hegység (Nagylapos), Nadap, Pápa, Rezi, Velem.

36. Eupithecia plumbeolata (Haworth, 1809)

Imágó: VI-VIII. Lelöhely: Rezi.

37. Eupithecia pusillata (Denis \& Schiffermüller, 1775) (= sobrinata (Hübner, 1817) Imágó: VIII-IX. Lelőhelyek: Balassagyarmat, Gerecse (Bocsájtó-völgy, Köpite-hegy, Vég-kő), Keszthelyi-hegység (Vadlány-barlang), Sopron, Tarhos.

38. Eupithecia pygmaeata (Hübner, 1799) (= pygmaearia (Boisduval, 1840) Imágó: VII-VIII. Lelöhelyek: Tata (Halas-tó, Öreg-tó). 
40. Eupithecia selinata Herrich-Schäffer, 1861

Imágó: V-VI. Lelöhelyek: Jászberény, Kaposvár, Keszthely (Nagylapos), Pacsa, Sárvár, Tata.

41. Eupithecia semigraphata Bruand, 1850

Imágó: VII-VIII. Lelőhelyek: Keszthelyi-hegység (Koponár, Nagylapos), Rezi, Velem.

42. Eupithecia silenicolata Mabille, 1867

1 , , Miskolc, 1974.VII.13. fénycsapda.

Jegyzet: Korzikáról leírt faj; diszjunkt, holomediterrán faunaelem. A Pannon-Kárpát térségben regresszióban van. Magyarországon a két generációs (IV-VI; VII-VIII.) $E$. silenicolata zengoensis Fazekas, 1979 él.

43. Eupithecia simpliciata (Haworth, 1809) (= subnotata Hübner, 1813)

Imágó: VII-VIII. Lelőhelyek: Balassagyarmat, Gönyü, Tata, Tarhos.

44. Eupithecia sinuosaria (Eversmann, 1848)

2 Ō, Tanakajd, 1976.VI.27; 1978.VII.3. fénycsapda.

Jegyzet: A faj részletes földrajzi elterjedésével, bionómiájával egy korábbi munkámban foglalkoztam (Fazekas 2012, pp. 51-53, 1-2. ábra). Nyugat-Magyarországon Tanakajd a második lelőhelye. Főként a Dunántúlról ill. az Északi-középhegységből vannak szórványos adatai.

45. Eupithecia subfuscata (Haworth, 1809) (= castigata (Hübner, 1813)

Imágó: V-VI. Lelöhelyek: Balassagyarmat, Gerecse (Vörös-rét, Zsidó-rét), Ivánc, Kám (Jeli-arborétum), Keszthely, Kisbér, Kőszeg, Rezi, Tata, Tardosbánya, Várgesztes.

46. Eupithecia succenturiata (Linnaeus, 1758)

Imágó: VI., VIII. Lelőhelyek: Bársonyos, Bokod, Brennbergbánya, Kaposvár, Keszthely, Kisbér, Rezi, Tata.

47. Eupithecia subumbrata (Denis \& Schiffermüller, 1775)

Imágó: VI-VII. Lelöhely: Ivánc.

48. Eupithecia tantillaria Boisduval, 1840

Imágó: IV-VI. Lelőhelyek: Balassagyarmat, Brennbergbánya, Ivánc, Kám, Koponár, Rezi, Sopron, Tata.

49. Eupithecia tenuiata (Hübner, 1813)

Imágó: VI-VIII. Lelőhelyek: Bakony (Darvas-tó), Brennbergbánya, Tata (Halas-tó).

50. Eupithecia tripunctaria Herrich-Schäffer, 1852

Imágó: IV-V; VII. Lelőhelyek: Balassagyarmat, Brennbergbánya, Gerecse (Alsóvadács), Ivánc, Kaposvár, Keszthely, Pacsa, Rezi, Sárvár, Somlóvásárhely, Tata.

51. Eupithecia trisignaria Herrich-Schäffer, 1848

1 †, Brennbergbánya, 1981.6.11., fénycsapda.

52. Eupithecia valerianata (Hübner, 1813)

1 ㅇ, Brennbergbánya, 1981.6.9. fénycsapda. 
Jegyzet: Euro-kaukázusi faunaelem (Mironov 2003); hazánkban igen lokális és ritka. Magyarországi bionómiája alig ismert, további vizsgálatok szükségesek. Preferált habitatjai a ligeterdők, a magaskórósok és a nedves rétek.

53 Eupithecia venosata (Fabricius, 1787)

Imágó: V-VII. Lelőhelyek: Baj, Bakony (Széki-erdő), Csopak, Kisbér, Pacsa, Rezi.

54. Eupithecia veratraria Herrich-Schäffer, 1850

Imágó: VI-VII.Lelöhelyek: Gerecse(Alsóvadács), Keszthelyi-hegység(Fagyoskereszt, Puskaporos allé), Rezi, Somlóvásárhely.

Jegyzet: Több központú, eurázsiai elterjedésü, alfajokra tagolódó faj; föként a mezo- és hygrofil réttársulásokban, magaskórósokban gyüjthető. Hazánkban regresszióban van.

55. Eupithecia virgaureata Doubleday, 1861

Imágó: IV-V; VII-VIII. Lelöhelyek: Balassagyarmat, Budai-hegyek (Irhás-árok), Csopak, Gerecse (Zsidó-hegy), Hegyeshalom, Ivánc, Kaposvár, Keszthelyi-hegység (Nagylapos), Nagyharsány, Pacsa, Sárvár, Tata („Halastavak”).

56. Eupithecia vulgata (Haworth, 1809)

Imágó: IV-VI; VIII. Lelőhelyek: Balassagyarmat, Brennbergbánya, Fácánkert, Kaposvár, Keszthely, Kisbér, Pacsa, Pécs (Jakab-hegy), Rezi, Sárvár, Szár, Tanakajd, Tass, Tata.

57. Gymnoscelis rufifasciata (Haworth, 1809) (= pumilata (Hübner, 1813)

Imágó: VI-IX. Lelőhelyek: Alsóvadács (Gerecse), Budapest (Orbán-hegy), Csákvár, Csopak, Gönyü, Keszthely, Nadap, Nagytétény, Tata.

58. Pasiphila chloerata (Mabille, 1870)

1 ex (hiányzik a potroh), Keszthely, 1978.V.30; 1 đ̊, Tata (Remeteség), 1982.6.23. leg. Herczig B.

Jegyzet: Japántól a Brit-szigetekig elterjedt. Hazánkban ritka és lokális májustól júliusig; föként kökény cserjésekben, karsztbokorerdő-sziklagyep mozaikokban, erdőszegélyeken, mezsgyéken, dombsági legelökön és szölöskertekben.

59. Pasiphila debiliata (Hübner, 1817)

1 ふૈ, Kőszeg (Király-völgy) 1979.6.2. leg. Herczig B.; 1 đે, Szár, Lankapuszta, 1981.6.1. fénycsapda.

Jegyzet: Japántól a Brit-szigetekig elterjedt, politipikus, monofág faj (Vaccinium spp.). Gyüjtötték fenyvesekben, bükkösökben és gyertyános tölgyesekben.

60. Pasiphila rectangulata (Linnaeus, 1758)

Imágó: V-VI; VIII. Lelöhelyek: Brennbergbánya, Gerecse (Kőpite-hegy), Keszthely, Pápa, Rezi, Tata.

Megjegyzés: A hazai gyüjteményekben ill. irodalomban korábban az Eupiheciini-k közé/közelébe sorolták az Anticollix sparsata-t. Újabb rendszertani helye: Geometridae, Larentinae, Melanthiini. A faj adatai a Herczig-gyüjteményben a következők:

Anticollix sparsata (Treitschke, 1828)

Imágó: V-VII; IX. Lelőhelyek: Bakony (Széki-erdő), Brennbergbánya, Hegyeshalom, Ivánc, Ócsa, Rezi, Sárvár, Várgesztes. 


\section{Összefoglalás}

A tanulmány 86 magyarországi lelőhelyről 60 Eupitheciini faj fanunisztikai, fenológiai és részben bionómiai, taxonómiai vizsgálati eredményeit közli. Megállapítja, hogy az Eupithecia ericeata a Mecsekben, míg az Eupithecia intricata az Alföldön új fajok; az Eupithecia nanata pedig az Örségi Nemzeti Park faunájában új taxon. Az Eupithecia breviculata magyarországi populációk erősen izoláltak a mediterrán térségek népességeitől. A veszélyeztetett, regresszióban lévő Eupithecia gueneata Magyarországon föként a száraz gyepekben, a kaszálóréteken, a sziklagyepekben, a lejtősztyeppeken és a karsztbokorerdőkben gyüjtötték; igen lokálisan.

Kevésbé ismert az Eupithecia insigniata faj életciklusa; faunaelem és faunakomponens besorolása pedig további vizsgálatokat igényel. Az Eupithecia inturbata-t Európában univoltin fajnak tekintik; az imágók repülési adatait föként júniustól szeptemberig közölték. Az április magyar példány nagy valószínüséggel két generációra utal, de ezt további kutatásokat igényel.

\section{Köszönetnyilvánítás}

Megköszönöm Herczig Bélának (Tata) a vizsgálatok nyújtott információit, köszönöm továbbá Ábrahám Leventének (Kaposvár), hogy a gyüjtemény revízióját lehetővé tette.

\section{Irodalom - References}

FAZEKAS I. 2012: Magyar Eupithecia tanulmányok (I.): Eupithecia sinuosaria (Eversmann, 1848), E. unedonata Mabille, 1868, E. expallidata Doubleday, 1856. [Hungarian Eupithecia studies (No. 1). - e-Acta Naturalia Pannonica 3: 49-58.

FAZEKAS I. 2016: Magyar Eupitheciini tanulmányok 4. Az Eupithecia catharinae Vojnits, 1969 típusanyagának revíziója | Hungarian Eupitheciini studies, No. 4. Revision of Eupithecia catharinae Vojnits, 1969 type material (Lepidoptera: Geometridae). - e-Acta Naturalia Pannonica 10: 5-12.

FAzEKAS I. 2017: Magyar Eupitheciini tanulmányok 5. A kaposvári Rippl-Rónai Múzeum Eupitheciini gyüjteményé | Hungarian Eupitheciini studies 5. Collection of Rippl-Rónai Museum, Kaposvár (Lepidoptera: Geometridae). - Natura Somogyiensis 30: 139-178.

Mironov V. 2003: Larentiinae II. (Perizomini and Eupitheciini). In A. Hausmann (ed.): The Geometrid Moths of Europe 4: 1-463. 